\title{
As representações midiáticas da transexualidade na telenovela A força do querer
}

\section{Tarcyanie Cajueiro Santos}

Doutora; Universidade de Sorocaba, Sorocaba, SP, Brasil tarcyaniecs@gmail.com

\section{Georgia Mattos}

Doutoranda; Universidade de Sorocaba, Sorocaba, Brasil georgia.jor@gmail.com

\section{Resumo}

Este artigo reflete sobre a representação que a telenovela $A$ força do querer, da Rede Globo, construiu sobre a transexualidade, por meio da/do personagem Ivana/Ivan. A análise do trabalho se utiliza do instrumento analítico do Circuito da Cultura, aporte teórico-metodológico dos Estudos Culturais, que compreende cinco processos distintos - representação, identidade, produção, consumo e regulação - como responsáveis por produzir significados na sociedade. São processos diferenciados que se articulam na construção de sentidos. Neste artigo, apresenta-se o conteúdo trabalhado no eixo Representação, com o apoio teórico dos estudos queer de Judith Butler. $O$ estudo conclui que a telenovela teve a intenção de promover um discurso a favor da diversidade, desmistificando concepções essencialistas e apontando para novas possibilidades de identidades generificadas, trazidas à tona a partir da experiência da transexualidade. Ainda assim, a telenovela construiu um sujeito transexual de acordo com os parâmetros do discurso médico e, dessa forma, sua representação estabelece uma verdade sobre a transexualidade, que confina a identidade transexual aos padrões rígidos do que é ser transexual, deixando de lado as diversidades e as pluralidades que existem em cada experiência.

\section{Palavras-chave}

Transexualidade. Representação. Estudos Queer. Telenovela.

\section{Introdução}

A telenovela brasileira é um produto cultural que ultrapassa o mero entretenimento, revelando aspectos socioculturais e identitários de um país continental e complexo. Suas representações, como aponta Lopes (2003), dão ênfase à realidade brasileira, que se utiliza de repertórios nacionais de acordo com o momento em que são exibidos. Segundo a autora, 
a "[...] novela passou a ser um dos mais importantes e amplos espaços de problematização do Brasil, das intimidades privadas às públicas." (LOPES, 2003, p. 25). Através dessa propriedade, em incorporar elementos da realidade sociocultural do país, a telenovela viabiliza um significativo debate sobre o cotidiano brasileiro. Ao estar presente há mais de 60 anos no país, funciona como mediador cultural e aponta para questões presentes no cotidiano dos brasileiros, inserindo temáticas muitas vezes ainda pouco abordadas pela sociedade, como as relativas às questões LGBT, especialmente à transexualidade.

A força do querer foi a primeira telenovela brasileira a exibir um/uma personagem transexual como coprotagonista, trazendo os desdobramentos da transexualidade como um dos temas centrais da trama. De autoria de Glória Perez e com direção artística de Rogério Gomes, a telenovela estreou em 3 de abril de 2017, na Rede Globo, e ficou no ar por quase sete meses. Durante a sua exibição, alcançou altos índices de audiência, chegando ao seu ápice no último capítulo, de número 172, exibido no dia 20 de outubro de 2017, com 50 pontos em São Paulo e 49 no Rio de Janeiro (FINAL..., 2017). Como o título indica, o tema principal da telenovela é os "quereres" da vida, em relação ao amor, ao dinheiro, ao sucesso, à identidade, ao poder e/ou realização profissional. A trama abordou diferentes quereres e desejos de seus personagens. 0 tema sobre o "querer" foi exposto na telenovela mediante o embate entre as escolhas dos/das personagens e os limites éticos e morais pelos quais passam a sociedade brasileira. Neste artigo, pretendemos refletir sobre a representação da transexualidade na telenovela A força do querer, de 2017, por meio da/do personagem Ivana/Ivan.

Para tanto, a análise do trabalho se utiliza do instrumento analítico do Circuito da Cultura, desenvolvido por Paul du Gay et al. (1997), aporte teórico-metodológico dos Estudos Culturais. Essa perspectiva metodológica estabelece cinco processos distintos representação, identidade, produção, consumo e regulação, como responsáveis por produzir os significados na sociedade. São processos diferenciados que se articulam na construção de sentidos. Nessa concepção, a representação é entendida como os significados atribuídos a um determinado artefato/produto cultural; que consequentemente, associa-se a certas identidades, as quais correspondem à forma como são representadas; a produção, por sua vez, refere-se às maneiras pelas quais o artefato é produzido; a regulação trata do poder que é exercido pelo/no artefato; e o consumo é o momento em que as pessoas fazem uso desse artefato/produto. Assim, o Circuito da Cultura possibilita estudar e compreender o processo comunicativo enquanto um processo também cultural que contribui para formular as práticas sociais. Neste texto, apresentamos o conteúdo trabalhado no eixo Representação, amparado em Stuart Hall (1997). 
Além de discutirmos o conceito de representação ancorado em Stuart Hall (1997), discorremos sobre o conceito de identidade em Woodward (2014), como também, tomamos como base os estudos de gênero da autora Judith Butler (2003), principalmente, em sua teoria da performatividade de gênero. Trabalhamos sobre os significados atribuídos na representação que a telenovela construiu sobre as relações de gênero e transexualidade, a partir do aporte teórico dos estudos queer. A análise é feita sobre a questão da transexualidade, por meio da representação da/do personagem Ivana/Ivan (Carol Duarte), que passou pelas fases de inadequação ao gênero feminino, descobriu-se homem trans e decidiu realizar a transição de gênero, para entendermos quais os sentidos e significados construídos sobre a experiência transexual. 0 corpus da análise versa sobre o percurso identitário de Ivana/Ivan, reproduzindo e analisando trechos da telenovela, nos quais as questões relativas à representação da identidade trans, assim como as de gênero, aparecem.

\section{Sobre o conceito de representação}

Enquanto um produto cultural, que une tanto entretenimento quanto informação e organiza práticas sociais, a telenovela produz significados e sistemas simbólicos sobre os quais são reproduzidas representações, que incidem sobre as identidades. A representação classifica o mundo e as relações sociais em seu interior, constituindo-se como "[...] uma parte essencial do processo pelo qual o sentido é produzido e trocado entre membros de uma cultura. Ela envolve o uso da linguagem, de signos e imagens que respondem por ou representam coisas." (HALL, 1997, p. 15, tradução nossa), e se dá por meio de dois "sistemas de representação". Primeiro, o conjunto de conceitos que criamos para correlacionar as coisas - pessoas, objetos, eventos, ideias abstratas, etc. - em nossa mente; e o segundo, refere-se à linguagem utilizada para expressar esses conceitos - linguagem imagética, sonora, escrita, oral, etc., assim, a linguagem consiste em signos organizados em várias relações.

Para interpretar os sentidos dados nos mais variados modos representacionais, é preciso ter acesso a esses dois sistemas de representação: aos conceitos sobre determinada "coisa" e ao sistema de linguagem que expressa e carrega alguma semelhança com a "coisa" real. 'A relação entre 'coisas', conceitos e signos repousa no coração da produção do sentido na linguagem. 0 processo que liga esses três elementos juntos é o que nós chamamos 'representação'." (HALL, 1997, p. 19, tradução nossa). 0 conceito de transexualidade, ou do que é ser transexual e a linguagem audiovisual, constroem a pessoa/experiência transexual carregada de significados. 0 sentido é, assim, construído pelo sistema de representação, que 
não é um reflexo do social, mas uma constituição da cultura, que leva marcadores que contribuem para a manutenção da ordem social e reproduz binarismos que constroem e/ou estabelecem as normalidades e assimetrias.

A telenovela, seguindo essa perspectiva, exerce relações de poder constituindo-se como uma representação ao dar visibilidade a certos temas, como é o caso do discurso sobre a transexualidade e, consequentemente, sobre as relações de gênero daí derivadas. Woodward (2014) aponta que os diferentes sistemas de representação - cinema, publicidade, telenovela, entre outros - possuem profunda influência sobre como as identidades são formadas, ao estabelecer as posições em que o sujeito pode tomar, mediante o processo de identificação. As posições que assumimos e com as quais nos identificamos constituem nossas identidades (WOODWARD, 2014). Nessa esfera, a questão que Woodward (2014) levanta é sobre as relações de poder que estão imbricadas na prática da representação, ao privilegiar certos significados relativos a outros. Isso inclui o poder, precisamente, de definir quem é incluído e quem é excluído, ou seja, quais identidades são legitimadas e quais são marcadas pela diferença. A identidade e a diferença estão, desse modo, estritamente ligadas com as relações de poder. Como reitera Silva (2014, p. 91), "Quem tem poder de representar, tem o poder de definir e determinar a identidade.". Para ele, tanto a identidade quanto a diferença fazem parte da relação de poder, que não são somente definidas discursivamente pelos sistemas de representação, mas impostas por eles, numa relação de constantes disputas. Woodward (2014) salienta que a diferença é aquilo que separa uma identidade da outra. A marcação da diferença é o próprio elemento-chave para a constituição da identidade. Segundo a autora, a identidade é relacional, no sentido de que para existir, depende de algo que está fora dela, precisa se distinguir do que ela não é. Hall (2014, p. 110) concorda e afirma que “[...] toda identidade tem necessidade daquilo que lhe 'falta' [...]", pois é a partir da marcação da diferença, daquilo que "lhe falta" que a identidade é construída como tal. Assim, a identidade depende da diferença. As identidades consideradas diferentes, na maioria das vezes, são tachadas como estranhas, presumidas como desviantes. As construções dos significados dados às identidades funcionam discursivamente para separar aquilo que é marcado, daquilo que não é. Como exemplo, a identidade de gênero, em que o/a transexual é o/a outro/a, marcado/a pela sua "diferença" com as identidades não transexuais. Nesse sentido, Silva (2014) também cita que é a sexualidade homossexual que é "sexualizada", então marcada, e não a heterossexual. E essas diferenças são produzidas pelo poder que as práticas de representação exercem na sociedade. Fixar uma determinada identidade como a norma é uma das formas privilegiadas de hierarquização das identidades e das diferenças. A normalização é um dos processos mais 
sutis pelos quais o poder se manifesta no campo da identidade e da diferença. Vejamos, então, como ocorre à manifestação da relação entre identidade e diferença a partir dos estudos de gênero em Butler.

\section{As relações de gênero em Judith Butler}

Butler, ao colocar em xeque o essencialismo a categoria sujeito, buscando compreender sua formação no interior de estruturas de poder sexuais e generificadas, tem sido considerada uma das principais expoentes dos estudos queer. 0 ponto central dos estudos queer é questionar a oposição binária heterossexualidade/ homossexualidade, através de uma política do conhecimento cultural. De acordo com Louro (2016, p. 62), dentro desta teoria, a "[...] homossexualidade é analisada como parte de um regime de poder/saber (mais do que uma identidade social minoritária).”. Isso mostra que a questão principal de análise deixa de ser a identidade propriamente para atentar-se à questão cultural, suas estruturas linguísticas e discursivas. "A expressão 'queer' constitui uma apropriação radical de um termo que tinha sido usado anteriormente para ofender e insultar e, seu radicalismo reside, pelo menos em parte, na sua resistência à definição - por assim dizer - fácil." (SALIH, 2015, p.19). Não há uma fixidez no conceito, mas um deslizar na indeterminação e transitorialidade de identidades sexuadas e generificadas. Desta forma, os estudos queer rejeitam a premissa de que determinado gênero indicará determinado desejo, como se o sexo fosse algo natural, anterior à cultura. É o que Butler (2003) chama de a forma "compulsória da sexualidade", que consiste em aceitar a heterossexualidade como a norma natural. A partir desse pressuposto, aqueles que não seguem à norma são considerados estranhos, mas estranhos necessários. Segundo Louro (2016, p. 68), “[...] esses sujeitos 'marginalizados' continuam necessários, já que servem para circunscrever os contornos daqueles que são normais e que, de fato, se constituem nos sujeitos que importam.." Como explicar, então, os desviantes dentro da lógica binária e natural? Para a autora, isso é possível somente quando entendemos que o sexo também é um constructo cultural.

Ao considerar o extenso estudo de Butler (2003) sobre as identidades generificada e sexuada, escolhemos discorrer sobre alguns dos conceitos presentes em sua obra "Problemas de Gênero", principalmente, sobre a teoria da performatividade. Para a autora, a identidade de gênero - a relação entre sexo, gênero, prática sexual e desejo - não ocorre de forma causal, mas é efeito de práticas discursivas que regulam e normatizam as identidades inteligíveis. Neste sentido, Butler (2003) desenvolve uma teoria da performatividade ao criticar a noção de sexo como uma substância permanente, que considera o sexo e o corpo 
como entidades materiais e naturais, opondo-se a ideia de gênero como um substantivo e reforça que "[...] o gênero não é um substantivo, mas tampouco é um conjunto de atributos flutuantes, pois seu efeito substantivo é performativamente produzido e imposto pelas práticas reguladoras da coerência do gênero." (BUTLER, 2003, p. 48). Na perspectiva da performatividade de gênero:

0 gênero é a estilização repetida do corpo, um conjunto de atos repetidos no interior de uma estrutura reguladora altamente rígida, a qual se cristaliza no tempo para produzir a aparência de uma substância, de uma classe natural de ser. A genealogia política das ontologias do gênero, em sendo bem sucedida, desconstruiria a aparência substantiva do gênero, desmembrando-a em seus atos constitutivos, e explicaria e localizaria esses atos no interior das estruturas compulsórias criadas pelas várias forças que policiam a aparência social do gênero. (BUTLER, 2003, p. 59).

Nessa concepção, a identidade de gênero é uma prática discursiva contínua, que se constrói a partir da repetição de atos ao longo do tempo. Isso permite compreender, segundo Butler (2003), o quanto as noções de sexo essencial e de feminilidade ou masculinidade verdadeiras e permanentes são constituídas de forma a ocultar o caráter performativo, que significa incorporar as marcas de gênero.

Ao compreender a identidade de gênero como uma construção performática, enquanto efeito dos discursos de poder sucedido ao longo do tempo, Butler (2003) incita que o sujeito é um termo em processo e, com isso, suas ações ou expressões não partem propriamente dele, mas das relações culturais. "Com efeito, a fonte da ação pessoal e política não provém do indivíduo, mas se dá nas e pelas trocas culturais complexas [...]" (BUTLER, 2003, p. 183). Diante dessa constatação, Salih (2017, p. 89) reitera que "[...] gênero não é algo que somos, é algo que fazemos [...]", então, ao invés de ser considerado como um substantivo, o gênero é um verbo, pois se constitui numa sequência de atos.

Butler (2003) afirma, entretanto, que mesmo o sujeito sendo culturalmente construído, não elimina o fato de ser também dotado de ação, portanto, não se trata de eliminar a ação do sujeito, mas de entender que essa ação não é realizada por um sujeito que tenha um "eu" pré-discursivo; e mais importante, que ser constituído pelo discurso não significa ser determinado por ele, o que não exclui a possibilidade de ação. Butler (2003) afirma que o sujeito negocia suas construções. É nesse ponto de negociação que emergem as possibilidades de identidades subversivas. Todavia, como Butler (2003) adverte, não há possibilidade de ação ou realidade fora das práticas discursivas, que mantêm a inteligibilidade das identidades nas práticas repetitivas de gênero. Assim, repetir tais 
práticas é inevitável, a tarefa consiste em como repetir, como sugere Butler (2003), repetir afastando-se das normas de gênero que facultam a própria repetição. Por isso, não existe toda e qualquer nova possibilidade, mas trata-se de redescrever as possibilidades existentes no domínio da cultura.

Se a subversão for possível, será uma subversão a partir de dentro dos termos da lei, por meio das possibilidades que surgem quando ela se vira contra a si mesma e gera metamorfoses inesperadas. 0 corpo culturalmente construído será então libertado, não para seu passado "natural", nem para seus prazeres originais, mas para um futuro aberto de possibilidades culturais. (BUTLER, 2003, p. 139).

Desse modo, as possibilidades de subversão das identidades de gênero só podem ocorrer dentro dos termos da cultura; não existe realidade ou práticas fora dela. As próprias produções e práticas discursivas presumem, de antemão, as possibilidades realizáveis de configurações de gênero na cultura, que estabelecem os limites de uma experiência discursivamente condicionada. Para a autora, a possibilidade de subversão se dá no modo de repensar criticamente as possibilidades que já existem nos próprios termos do poder; essa conversão não se trata de uma consolidação, mas como Butler (2003) afirma, trata-se de um deslocamento.

Não significa subverter a ponto de romper totalmente com as normas inteligíveis estipuladas, o que ela chama de "ordem compulsória da heterossexualidade" - gêneros inteligíveis, ou seja, os gêneros que mantêm a coerência entre sexo, gênero, prática sexual e desejo, mas de desestruturar essas normas que regulam e autonomizam as identidades que são sancionadas e legitimadas das que são excluídas e não podem ser inteligivelmente reconhecidas, pois "[...] a 'coerência' e a 'continuidade' da 'pessoa' não são características lógicas ou analíticas da condição da pessoa, mas, ao contrário, normas de inteligibilidade socialmente instituídas e mantidas." (BUTLER, 2003, p. 38).

Dentro do interior das relações de poder, é preciso perceber criticamente que as práticas proibitivas são estabelecidas pelo interesse das estruturas de poder/saber que justificam e respaldam-se em discursos da natureza biológica, quando, na verdade, tratam-se de discursos políticos. Essa matriz cultural da identidade de gênero impede que outros tipos de identidades possam existir, aquelas em que o gênero, de acordo com a autora, não decorre do sexo, ou aquelas em que as práticas do desejo não decorrem nem do sexo e nem do gênero, são identidades de gênero que não se conformam às normas da inteligibilidade cultural. Essa "incoerência”, que "[...] parecem ser meras falhas do desenvolvimento ou 
impossibilidades lógicas [...]", como afirma Butler (2003, p. 39), permite problematizar não somente a ideia de um gênero culturalmente construído, mas também questionar sobre o sexo como biologicamente imutável.

Para a autora, não basta considerar o gênero apenas como a inscrição cultural de significado num determinado sexo, como se esse fosse previamente dado, mas apontar também todo o aparato de produção em que os próprios sexos são estabelecidos. Assim, Butler (2003, p. 25) afirma que "[...] o gênero não está para a cultura como o sexo para a natureza [...]", pois o sexo também é um meio discursivo cultural, no qual essa natureza é produzida e estabelecida como pré-discursiva ou anterior à cultura. 0 gênero, portanto, não pode ser entendido como a expressão ou o reflexo do sexo.

A ordem compulsória da heterossexualidade estabelece somente uma forma inteligível de sexualidade - a heterossexual, e ainda, dada como naturalmente concebida. Para os estudos queer, a sexualidade é sempre construída nos termos dos discursos de poder e esse poder está inserido nos termos das convenções culturais heterossexuais. Percebe-se que, ao estabelecer o sexo como uma categoria invariável da natureza, reforçando-o na diferença entre feminino e masculino, cria-se uma posição política que favorece às necessidades estruturais e econômicas de uma sociedade heterossexista. Diante disso, Butler (2003) rompe com a dicotomia sexo e gênero, e avalia que o sexo não é tão fixo como supõe ser e que o gênero não é o resultado causal do sexo, mas é efeito dessa construção cultural que produz o sexo como pré-discursivo.

Butler (2003, p. 39) reforça que a persistência de identidades de gênero que não se conformam às normas "[...] criam oportunidades críticas de expor os limites e os objetivos reguladores desse campo de inteligibilidade e, consequentemente, de disseminar, nos próprios termos dessa matriz de inteligibilidade, matrizes rivais e subversivas de desordem do gênero.".

A partir dessa explanação, podemos considerar a pessoa transexual como uma identidade subversiva, ao reivindicar pertencer ao gênero e/ou corpo sexuado oposto; e considerando a relação de poder/saber que um produto midiático, como a telenovela, exerce em nossa cultura, analisaremos, no próximo tópico, como a telenovela $A$ força do querer, de 2017, construiu sua representação sobre a transexualidade.

\section{A força do querer e sua representação sobre a transexualidade}

Ivana é filha do empresário e advogado Eugênio Garcia (Dan Stulbach) e da socialite Joyce (Maria Fernanda Cândido). Junto aos problemas conjugais, eles lidam com os conflitos 
da filha Ivana (Carol Duarte), que quer resgatar sua identidade ao descobrir que é trans homem. A personagem Ivana, desde o início da telenovela, revela uma inconformidade consigo mesma, numa relação de conflito com o espelho, por não se reconhecer na imagem refletida, como ela conta numa das sessões de terapia, no capítulo do dia 17 de julho de 2017: “Não aguento mais olhar no espelho e não reconhecer a figura que o espelho tá mostrando, não sou eu! Não aguento mais brigar com meu corpo o tempo todo, sentir que meu corpo tá errado, sentir que eu tô numa embalagem trocada". Nesta fala, que exemplifica tantas outras da personagem, a telenovela coloca em questão a inadequação que Ivana tem com o seu gênero feminino, não somente em relação à sua imagem e ao seu corpo, mas em assumir os aspectos que envolvem o universo feminino, como as roupas consideradas próprias de seu gênero - vestidos, sapatos de salto alto, rendas, babados, maquiagem; e o comportamento considerado "adequado" da mulher na nossa sociedade, como delicadeza e passividade. Ao refutar esses protocolos, a personagem afirma se sentir "fora dos padrões", devido à sua incapacidade em corresponder com a ideia de feminino estabelecida na sociedade, agravado na trama, pela sua relação com a mãe, com quem trava constantes discussões sobre desempenhar sua feminilidade da maneira correta.

Muitos capítulos foram dedicados a mostrar a inadequação da personagem aos padrões (impostos) ao gênero feminino. Ivana se sente mais confortável com as camisas do irmão, preferindo um estilo mais "básico", com um tipo de roupa mais sóbria, determinado para os homens, demonstrando, assim, um desprendimento em se dedicar à produção mais trabalhosa, "exigida" para as mulheres.

Além da vestimenta, a personagem também se sente incomodada em ter de se comportar exatamente como é esperado que uma mulher se comporte socialmente. Em seu encontro com o namorado, Cláudio (Gabriel Stauffer), ao abrir a porta do carro, ele prontamente diz "opa, opa, calma, deixa comigo", ao que ela responde: "nossa, mas essa porta é tão pesada assim?". No restaurante, Cláudio puxa a cadeira para ela sentar, mas ela diz: "não precisa, eu já sei afastar uma cadeira, eu treinei em casa". É descumprida, assim, uma convenção cultural, em que o homem é ativo e, a mulher, passiva. Na cena, Ivana diz que ele está a tratando como se ela fosse uma criança, mas ele reitera: "não sei se você percebeu, mas eu tô tentando conquistar você". Dessa forma, Cláudio procura seguir as regras de um encontro romântico heterossexual, no qual cada um tem um papel estipulado e deve desempenha-lo como de praxe. No trecho a seguir, do capítulo do dia 11 de abril de 2017, Ivana conta sobre o encontro para a prima e amiga, Simone, relatando esse modelo de conduta: 
Ivana: Ele estava todo artificial, sabe, tava me tratando como se eu fosse uma criança, ele abria a porta do carro, puxava a cadeira... [...] 0 pior, Simone, foi quando a gente chegou no restaurante, o garçom trouxe a carta de vinho, começou o telefone sem fio. Ele perguntou o que eu queria, para ele falar para o garçom, sendo que o garçom tava aqui do meu lado, escutando tudo que eu tava falando.

Simone: Ele tava sendo cavalheiro, criatura! Gente, não é possível, qualquer mulher ia gostar de ser bem tratada por um homem cavalheiro.

Ivana: Simone, eu detesto esse joguinho, parece que você, sei lá, tem que se fingir de surda, cega. [...]. Parecia que a gente tava seguindo um script, representando um papel.

Nesta transcrição, Ivana chama de "joguinho" o fato do comportamento deles já ter sido preestabelecido, como se estivessem representando um papel. Mas é isso que fazemos socialmente, o que Butler (2003) denomina de performatividade. Representamos nossos gêneros por meio de um conjunto de atos repetidos, que são constituídos no interior de uma estrutura reguladora, que por se cristalizar no tempo, tem-se a falsa noção de ser natural. Ao transgredir à norma de gênero que determina a conduta adequada para o feminino, Ivana traz à tona o caráter performático dessa conduta. Pois, tornou-se uma obrigação social assumir as performances do gênero, qualquer outra forma de se comportar é considerada transgressora, fora da ordem, portanto, ilegítima. Na sociedade, só há lugar para o que é inteligível, então, a personagem precisa passar por um processo corretivo, no caso da telenovela, a terapia.

Numa tentativa de se adequar aos padrões femininos, recomendado pela sua terapeuta, que acredita que ela bloqueou o feminino que há dentro dela devido à expectativa exagerada da mãe, Ivana se esforça para cumprir com as exigências de "seu" gênero. Procura aprender a usar a paleta de sombras, a escolher as roupas "apropriadas" e, assim, conseguir fazer as "pazes com o feminino" e "recuperar" sua autoestima. Ao experimentar uma lingerie, que, segundo a prima, "não há nada mais feminino que isso", Ivana afirma se sentir “esquisita". Na transcrição abaixo, do capítulo do dia 11 de maio de 2017, Ivana conta para a terapeuta como se sentiu:

Ivana: É isso, a gente foi comprar um monte de lingerie.

Eva: E já usou?

Ivana: Não, não, a gente comprou hoje.

Eva: Mas já se imaginou usando?

Ivana: Ah, a Simone me fez experimentar tudo.

Eva: E como é que você se sentiu?

Ivana: Eu me senti fantasiada, pronta para ir num bloco, não sou eu, aquilo não tem nada a ver comigo. Não é que eu ache feio, eu acho bonito, ficou lindo na Simone, mas em mim, em mim destoa, eu me sinto uma bruta com aquelas rendinhas todas, tipo um elefante de saiote, sabe? 
Eva: Ah, Ivana, é natural esse estranhamento todo. Você tava ali tentando resgatar sua feminilidade, mas diante de outra pessoa, diante do olhar de outra pessoa, diante da expectativa de uma outra pessoa. E foi exatamente por isso que você sufocou a sua feminilidade, por receio de não corresponder às expectativas da sua mãe.

Ivana: Não sei, eu não me sinto encaixada em nenhuma explicação.

Eva: Sabe, descobrir a si mesmo leva tempo, e você já passou tempo demais tentando destruir, tentando construir, melhor dizendo, essa sua aversão ao feminino.

Neste diálogo, a psicóloga Eva (Ester Jablonski) interpreta o sentimento de inadequação de Ivana, partindo do pressuposto de que há uma feminilidade dentro dela, que com o tempo e com a ajuda profissional, conseguirá resgatá-la, como se possuísse em si mesma uma essência feminina. Num outro capítulo, dia 18 de maio de 2017, a terapeuta diz: “o seu feminino está aí, você sabe que está, o que nós estamos fazendo aqui é dizer para ela 'não tenha medo'". Com essa concepção, a terapeuta ignora a própria experiência da pessoa, sua própria condição, para insistir num ideal normativo construído socialmente. Sua postura é a da autoridade profissional, que atua para manter as normas de gênero, que "garantem" a inteligibilidade das identidades generificadas.

Em diferentes contextos, esse mesmo discurso é proferido por outros/as personagens, que entendem a feminilidade e a masculinidade como características intrínsecas do ser humano, naturais de cada indivíduo, como na seguinte transcrição, exibida no dia 9 de junho de 2017, num diálogo entre Ivana e sua mãe sobre os gostos de seu sobrinho, Ruyzinho (Lorenzo Souza), ainda bebê:

Ivana: Como é que ele tá?

Joyce: Ah, é um anjinho né. Ele é um anjinho.

Ivana: Muito bonitinho.

Joyce: Olha a titia. Sabe que eu já tô imaginando ele assim, pedalando aqueles carrinhos.

Ivana: Você nem sabe se ele vai gostar de carrinho.

Joyce: Mas claro que vai, ele é menino, meninos gostam de carrinho.

Ivana: Ah é? Nasce com bula, né? Então, se é menino vai gostar de carrinho, vai gostar de skate, de futebol.

Joyce: Ivana, do mesmo modo que as meninas gostam de maquiagem, de balé, de boneca. É assim, filha. Não é bebê?

Ivana: E quando não gostam? Eu nunca achei graça em boneca.

Joyce: Você, sabe o que você gostava? De me contestar, é isso, não é Ruyzinho? Ela gostava de me contestar.

Ivana: Não mãe, tô falando sério agora, não faz isso com o menino não, deixa ele crescer e falar do que gosta, ele nem sabe quem ele é e você já tá falando como ele deve ser.

Joyce: Ah, Ivana.

Ivana: Não, é mesmo, depois ele cresce e é diferente disso que você está falando. Ele vai ficar o resto da vida se sentindo desencaixado. 
Para Joyce (Maria Fernanda Cândido), mãe de Ivana, meninos já nascem gostando de carrinhos, ao passo que meninas gostam de maquiagem, de balé, numa clara ideia de que o gosto está automaticamente de acordo com os elementos determinados para cada gênero. É a personagem Ivana, por viver esse "desencaixe" consigo mesma, que contesta a estabilidade dessa norma. Num outro capítulo, Ritinha (Isis Valverde), mãe do menino, mostra os brinquedos que o pai comprou, carrinhos, bola, camiseta de futebol e, novamente, Ivana contesta: "mas, gente, deixa o menino escolher o que ele quer brincar, o menino mal nasceu e vocês já estão sufocando, e se ele não gostar de futebol?", mas sua mãe torna a reforçar que "todo menino gosta de futebol". Ivana começa a falar que nunca gostou de bonecas, "não achava a menor graça", e sempre preferiu andar de skate, de jogar bola, e sua mãe retruca, dizendo que "gostava era de ser rebelde isso sim, toda menina gosta de boneca", mas Ritinha concorda com Ivana e afirma que "também não gostava de boneca não, gostava era de nadar no rio, subir em árvore, soltar pipa", Joyce faz uma cara de desprezo e diz "subindo em árvore, menina, credo, isso é coisa de moleque". Neste ponto, é notório perceber que a telenovela, ao colocar em xeque a feminilidade natural da mulher, poderia, por outro lado, reforçar uma possível essência masculina na personagem Ivana, por se tratar de uma personagem transexual, mas entendemos que seu discurso foi elaborado para mostrar que não nascemos prontos e integralmente ligados a este ou aquele universo, instituído de forma binária entre o feminino e o masculino, em que o indivíduo se vê obrigado a se encaixar em um ou em outro. A transexualidade se refere, justamente, na percepção que a pessoa tem de si mesma, nas possíveis e variáveis identificações identitárias, que transpassam esse binarismo, desestabilizando-o.

No capítulo do dia 29 de setembro de 2017, Ivana/Ivan (no processo de transição) está com a prima Simone (Juliana Paiva) no consultório médico, que pergunta para uma mulher, que também aguarda ser atendida, quantos meses de gestação ela está e se é menino ou menina. A mulher responde "oito meses" e acrescenta: "é menino, mas eu demorei para fazer os exames e eu comprei tudo cor de rosa, é menino, agora vou ter que trocar tudo para azul", Ivan, então, comenta: "ah não, mas fica bonito rosa em menino também", mas a mulher estranha e declara: "que isso! imagina, coitada da criança, imagina!". A simples expressão "coitada da criança" revela a irregularidade em vestir um menino com a cor rosa, e indica os danos que isso causaria à criança, movendo-a de seu lugar determinado, de sua ordem normatizada: menino, masculino e heterossexual.

Ao representar várias situações e diálogos como estes, em que alguns personagens pensam de acordo com a ordem compulsória da heterossexualidade (BUTLER, 2003), ou seja, que o sexo determina o gênero - gosto, comportamento, preferências, e este determina 
o desejo, direcionado sempre para o sexo oposto, mostra também, outros/as personagens que contestam essa norma, contrapondo-a com seus argumentos provocativos. Assim, a telenovela faz uma clara alusão dos/das personagens que estão do lado "certo" e daqueles/as que são tachados/as de "ultrapassados", apegados/as a concepções já vencidas pela experiência humana, pelas práticas que não podem mais ser negadas. Seu discurso, desse modo, propõe um rompimento com esses antigos paradigmas. Ainda que mostre que muitos na sociedade pensam dessa forma, a telenovela sugere que no momento atual, esses preceitos não cabem mais. 0 espaço que antes era dado somente para as identidades inteligíveis, agora, revela-se como um espaço de todos e para todos, num discurso a favor da diversidade.

Como se pode ver no trecho abaixo, do dia 29 de agosto de 2017, quando Simone conta para seu pai que Ivana revelou para a família que é transexual:

Simone: Então, acho melhor você saber logo e por mim. Pai, a Ivana descobriu que é um trans.

Eurico: 0 que é?

Simone: Ela não é uma mulher, é um homem.

Eurico: Como é que é? Repete aí para eu entender.

Simone: Ela descobriu que é um trans homem, é quando a pessoa, pai, nasce num corpo que não é o dela, que ela não se identifica. No caso da Ivana, para ela, ela nasceu homem, se identifica com o gênero masculino, só que ela nasceu num corpo de mulher.

Eurico: Que isso? Que aberração é essa?

Simone: Não, não é aberração, é difícil de entender, eu sei, eu vou te explicar de novo...

Eurico: Não, não precisa me explicar nada não que eu já entendi muito bem, que isso, você tá querendo me dizer que a Ivana tá dizendo que ela é um homem, a Ivana tá dizendo isso?

Simone: A reunião que rolou ontem foi para isso, para ela contar para a família.

Eurico: E onde é que tá ela? Onde tá ela que não botaram numa camisa de força, não internaram essa menina ainda.

Simone: Pai, pelo amor de Deus, tem gente que nasce assim.

Eurico: Não, conversa. Ninguém nasce na coluna do meio, não, a pessoa nasce homem ou a pessoa nasce mulher, isso aí é gente encostada, a gente vê, ora.

Simone: Não, tem coisas que a gente olha e não vê. Esse é o caso do transgênero, parece menino, mas não é, parece menina, mas não é. Eu vou te mostrar, tem vários vídeos na internet de médicos explicando, psicólogos explicando.

Eurico: Ah meu Deus, tem até médico embarcando nessa também, era só o que faltava, isso é uma aberração ora, eu já sei, eu já sei, o negócio é contestar né? 0 negócio é contestar tudo que é normal, é isso que é.

Simone: Ninguém quer contestar nada, é o que eles sentem.

Eurico: Não, que sente, imagina só eu chegando aqui um dia e dizer 'Simone, olha minha filha, tá tudo errado, eu não sou seu pai, sou sua mãe'.

Simone: Pai, vamos combinar que no seu caso é praticamente impossível né. 
Eurico: Não, nada disso, isso é falta de pulso, perdi até a fome de comer, vou te falar um negócio, é falta de pulso dentro de casa.

O ponto de vista de Eurico (Humberto Martins), ao chamar de "aberração", considerando a transexualidade como uma escolha do indivíduo, ao dizer que "o negócio é contestar tudo que é normal", ou ainda, como se tratasse de uma doença, para colocar numa "camisa de força", revela não somente sua falta de entendimento sobre a questão, como transmite a ideia de alguém "antiquado". Mais do que mostrar alguém conservador, o discurso da telenovela busca mostrar que não há mais lugar para este tipo de pensamento e que continuar a defender uma posição como essa é se colocar numa posição de ignorância. Em contrapartida, a filha, por ter obtido informação sobre o assunto e conviver com essa experiência por meio de Ivana/Ivan, demonstra ter conhecimento e melhor compreensão, ainda que se trate de um assunto tão complexo.

Além de personagens como Simone, que passou a compreender melhor a questão, ou daqueles personagens que vivem a experiência da transexualidade, como Ivana/Ivan e T. (Tarso Brant), quem compartilhou sua história na trama, ou ainda a personagem Elis Miranda, travesti que se mostra muito entendida do assunto, em 1 de setembro de 2017 em diante, a nova psicóloga de Ivan também passa a explicitar a questão sob essa nova perspectiva, de forma teórica e, agora, representando uma profissional "atualizada", que entende, de fato, a questão. Essa compreensão é elucidada, no trecho a seguir, quando a psicóloga conversa com os pais de Ivan, após ele aparecer de barba e bigode:

Tereza: Bom, agora, o fato está posto, vocês não têm alternativa, vocês têm que encarar ou fugir, vocês têm que aceitar ou dar as costas.

Eugênio: Não vamos dar as costas para nossa filha.

Tereza: Filho.

Eugênio: Não, hã?

Tereza: Eugênio, não é uma filha, é um filho.

Eugênio: Não, Tereza.

Tereza: E não se tornou um filho agora, sempre foi.

Joyce: Não, isso não, ela não nasceu assim.

Tereza: Olha, Joyce, não existe só uma maneira de se definir o sexo de uma pessoa, não é só pelo aspecto físico, pelo que é a aparência, entende? Uma criança quando nasce, logo se diz é menino, é menina, aí aquela criaturinha cresce, sendo enquadrada na maneira como uma sociedade percebe os homens e as mulheres, só que muitas vezes não é a maneira como essa pessoa se percebe. A Ivana não se percebe como mulher.

As palavras da psicóloga são teóricas ao esclarecer sobre a transexualidade, sua última frase contém preceitos muito congruentes com os estudos queer. Sobre não ter uma só "maneira de se definir o sexo de uma pessoa, não é só pelo aspecto físico", o discurso se 
embasa no rompimento de uma natureza anterior à cultura, denuncia a estabilidade dicotômica entre sexo e gênero, concordando com Butler (2003), de que o sexo é tão culturalmente construído quanto o gênero e, desse modo, o sexo não é fixo como se presume e nem o gênero é o resultado causal do sexo. Isso causa certo estranhamento em alguns personagens. Ao se descobrir transexual, Ivana indaga a prima se ela já pensou que poderia não ser mulher, mas Simone prontamente responde: "prima, eu tô te vendo, que isso! A gente se conhece desde pequena, já te vi pelada várias vezes. Ivana, você é uma mulher!”. Em outro capítulo, Joyce, mãe de Ivana/Ivan, afirma que a viu nascer: "você não sabe o que você está dizendo, você nunca foi um menino, os médicos, as enfermeiras, eles me trouxeram, a minha menina". Essas afirmações declaram que conhecer o corpo de alguém, saber seu sexo confere legitimidade ao gênero; é a garantia de que não há qualquer outra possibilidade para o indivíduo. Mas, a transexualidade causa uma ruptura nessa falsa estabilidade, ela indica, ao contrário, quão cambiantes e mutáveis são as identidades generificadas, não se trata somente do indivíduo que nasceu num corpo errado, mas em como a sociedade construiu padrões determinantes para os indivíduos, estabelecendo as identidades legítimas das identidades consideradas desviantes.

A experiência transexual rompe com o binarismo feminino e masculino, expõe as muitas nuances que existem entre esses dois extremos, obrigando-nos a refletir sobre a solidez produzida pelas normas de gênero. Esse processo reflexivo é representado no capítulo do dia 30 de setembro de 2017, por meio do personagem Eugênio (Dan Stulbach), pai de Ivan, numa conversa com o filho Ruy (Fiuk), após Ivan descobrir que está grávido.

Ruy: Caramba né, pai? Que loucura tudo isso.

Eugênio: Quem sabe isso traz a Ivana de volta pra gente, quem sabe.

Ruy: Se for para parar com essa história aí de dizer que é homem.

Eugênio: Eu tenho lido muito sobre o assunto, sabe. É perturbador como a gente... como as coisas não são tão exatas, né. As coisas não são tão exatas como a gente cresce achando que são.

Ruy: É, sei lá. Do que você tá falando?

Eugênio: Ah, do preto no branco, é isso ou é aquilo, existem muitas camadas, muitas entre os dois extremos.

Ruy: Você tá dizendo que você realmente acha que a Ivana pode ser um homem? É isso? Não, né?

Eugênio: Um transhomem, Ruy. Um transhomem.

Ruy: Pai!

Eugênio: Impressiona o quanto a gente passa a vida inteira sem enxergar o que tá ali, do nosso lado. Tanta gente passando por esse drama e eu nunca percebi que elas existiam.

Neste diálogo, o irmão ainda se mostra relutante em admitir a condição de Ivan. Ao longo da trama, ele considera como um "surto" ou uma vontade de "chamar a atenção", e não 
aceita receber explicações sobre essa experiência. Já Eugênio, mesmo reconhecendo que é "perturbador como as coisas não são tão exatas", representa aquela pessoa que se dispõe a pensar sobre o assunto, e mais, que procura entender, informar-se, como descrito na frase "tenho lido muito sobre o assunto", ao contrário de sua esposa, Joyce, que não estava disposta a fazer esse movimento. No capítulo do dia 18 de setembro de 2017, Eugênio entrega o livro do João Nery - "Viagem Solitária" - para a esposa, diz que foi Ivana quem deu e ele leu para "entender o que está se passando com ela", mas Joyce, sem nem olhar para o livro, afirma: "ela pode doutrinar você, a mim não doutrina não". Ao colocar essas duas atitudes, o discurso da telenovela sinaliza, de um lado, uma postura considerada sensata, de pessoas instruídas e, do outro, uma forma antiquada e inflexível em lidar com a questão.

Se por um lado, essa representação permitiu que o/a telespectador/a pensasse e conhecesse a transexualidade; por outro, a telenovela construiu um sujeito transexual de acordo com os documentos oficiais que dão base para os programas de transgenitalização. A telenovela, ao se prender a padrões e regras do que é ou não é ser transexual, encaixou a transexualidade nos parâmetros do discurso médico. Não é possível classificar os/as transexuais como sujeitos que apenas desejam mudar a aparência ou o sexo, pois a própria transgenitalização não se limita à sexualidade, mas atravessa relações, a incoerência está em estabelecer uma verdade sobre a transexualidade, estipular um tipo de transexual universal. Como Bento (2008, p. 53) afirma: "As intersecções entre uma narrativa e outra não são suficientes para se concluir que haja um núcleo comum compartilhado por todos os que vivem a experiência transexual.". Isso não é negar que existe um coletivo que compartilha sentimentos e histórias em comum, mas não se pode deixar de considerar as diversidades e as pluralidades que existem em cada história de vida. A experiência transexual desperta para a vulnerabilidade de todas as identidades que se passam por fixas e coerentes, pois denuncia que o ideal identitário é inatingível para todas as pessoas. E as identidades - sejam elas quais forem - adquirem sentido por meio dos significados que são produzidos pelos sistemas de representação, portanto, são socialmente construídas no interior da representação, através da cultura.

\section{Considerações finais}

A representação da telenovela $A$ força do querer construiu uma identidade transexual baseada muito mais num padrão formulado oficialmente pelo saber/poder médico do que nas muitas possibilidades que existem socialmente, enquadrando o indivíduo transexual numa norma fixa e regular, que contradiz a diversidade da realidade. Por outro lado, 
colocou-se favorável às diferenças identitárias, outrora, banidas desse mesmo espaço representacional, dando visibilidade para as identidades marcadas por sua diferença. Ainda, contribuiu para alertar a sociedade sobre a violência contra a comunidade LGBT, no intuito de combater a transfobia e/ou a LGBTfobia.

Não é de hoje que as telenovelas da Rede Globo são pautadas por temas agendados de acordo com interesses comerciais, mas que também cumprem um papel social relevante. No que diz respeito à Glória Perez, isso se torna estratégia singular (GOMES, 2013), constituindo-se como uma de suas marcas. Ao lado das narrativas privadas sobre temáticas de domínio público, as telenovelas de Glória Perez são conhecidas, igualmente, pela inserção de pessoas reais, que expõem suas histórias de vida na trama. Essa caracterização compôs a promoção de um discurso a favor da diversidade, desmistificando concepções essencialistas e apontando para uma realidade, que rompe com antigos paradigmas e, apresenta em seu lugar, o conhecimento de novas possibilidades das identidades generificadas, trazidas à tona a partir da experiência da transexualidade. Acreditamos que seu discurso muito se associa aos conceitos de Butler (2003), principalmente, no que diz respeito à ideia de subversão, que se refere ao deslocamento das identidades generificadas, que passam a transitar e a transpassar por/entre os dois universos estabelecidos. Essas novas possibilidades, consideradas "transgressoras", reformulam e desestruturam as normas de gênero que regulam e autonomizam as identidades, permitindo repensar criticamente os atos repetitivos, performativos de gênero e denunciar a estabilidade da identidade de gênero como uma construção fixa e coerente.

Ainda assim, não se pode deixar de pontuar que a telenovela é um produto midiático, pautado por interesses mercadológicos e por modelos de representação excludentes, que contribuem para a manutenção da ordem social, perpetuando diferenças e desigualdades. A prática de inserir temas sociais na teledramaturgia é vista por Dourado (2011) como uma das estratégias comunicacionais de conquistar a credibilidade do público e alcançar altos índices de audiência para, consequentemente, despertar o interesse de anunciantes. A pauta desses temas é, em grande parte, agendada por interesses comerciais, além de concentrarem as mobilizações num período pontual de tempo, ou seja, encerrada a ficção, o tema volta a ficar submerso. Para a autora, a cidadania midiática é bastante precária por ser construída a partir de lógicas privadas, voltada aos interesses mercadológicos. Mesmo quando a ação parte de autores de ficção, os temas abordados seguem as regras da empresa de comunicação, tornando-se, com isso, limitados e pouco aprofundados. Ao apontar o que é aceitável e inaceitável, patológico e normal, feminino e masculino, a telenovela reproduz normalidades e legitima assimetrias e desigualdades políticas, econômicas e sociais. Desta 
forma, a telenovela, ou qualquer outro produto televisivo, mesmo agindo como ator social, reproduz realidades fragmentadas ou rearticuladas, as quais privilegiam os interesses mercadológicos.

\section{Referências}

BENTO, Berenice. 0 que é Transexualidade. São Paulo: Brasiliense, 2008.

BUTLER, Judith. Problemas de Gênero: feminismo e subversão da identidade. Rio de Janeiro: Civilização Brasileira, 2003.

DOURADO, Jacqueline Lima. Rede Globo: mercado ou cidadania? Teresina: EDUFPI, 2011.

DU GAY, Paul et al. Doing Cultural Studies: the story of the Sony Walkman. Londres: Sage, 1997.

FINAL de 'A Força do Querer' bate os 50 pontos de audiência. Veja, São Paulo, 23 out. 2017. Disponível em: http://veja.abril.com.br/entretenimento/final-de-a-forca-do-querer-bate-os50-pontos-de-audiencia/. Acesso em: 30 out. 2017.

GOMES, Juliana Oliveira. Arebaba! Telenovela e autoria. Caminho das Índias, Glória Perez e os relatos de migrantes e viajantes. 2013. Dissertação (Mestrado em Comunicação e Culturas Contemporâneas) - Faculdade de Comunicação, Universidade Federal da Bahia, Salvador, 2013.

HALL, Stuart. Quem precisa da identidade. SILVA, Tomaz Tadeu. A produção social da identidade e da diferença. In: SILVA, Tomaz Tadeu (org.). Identidade e diferença: a perspectiva dos estudos culturais. 15. ed. Petrópolis: Vozes, 2014. p. 103-133.

HALL, Stuart. The work of representation. In: HALL, Stuart (dit.). Representation. Cultural representation and cultural signifying practices. London: Sage, 1997. p. 13-74.

LOPES, Maria Immacolata Vassallo de. Telenovela brasileira: uma narrativa sobre a nação. Comunicação e Educação, São Paulo, v. 26, p. 17-34, jan./abr. 2003.

LOURO, Guacira Lopes. Um corpo estranho: ensaios sobre sexualidade e teoria queer. 2. ed. Belo Horizonte: Autêntica, 2016.

SALIH, Sara. Judith Butler e a Teoria Queer. 1. ed. Belo Horizonte: Autêntica, 2017.

SILVA, Tomaz Tadeu. A produção social da identidade e da diferença. In: SILVA, Tomaz Tadeu (org.). Identidade e diferença: a perspectiva dos estudos culturais. 15. ed. Petrópolis: Vozes, 2014. p. 73-102.

WOODWARD, Kathryn. Identidade e diferença: uma introdução teórica e conceitual. In: SILVA, Tomaz Tadeu (org.). Identidade e diferença: a perspectiva dos estudos culturais. 15. ed. Petrópolis: Vozes, 2014. p. 7-72. 


\title{
The media representations of transexuality in telenovela $A$ força do querer
}

\begin{abstract}
This article reflects on the representation that the soap opera $A$ força do querer of Rede Globo built on transsexuality through the character Ivana/Ivan. The analysis of the work is based on the analytical instrument of the Culture Circuit, a theoretical and methodological contribution of Cultural Studies (DU GAY et al., 1997), which comprises five distinct processes - representation, identity, production, consumption and regulation - as responsible for producing meanings in society. They are differentiated processes that are articulated in the construction of meanings. In this article, we present the content worked on the Representation axis, with the theoretical support of the queer studies of Judith Butler. The study concludes that the telenovela had an intention to promote a discourse in favor of diversity, demystifying essentialist conceptions and pointing to the new possibilities of generalized identities, brought to the surface from the experience of transsexuality. Nevertheless, the telenovela constructed a transsexual subject according to the parameters of the medical discourse and, in this way, its representation establishes a truth about the transsexuality, that confines the transsexual identity to the rigid standards of what it is to be transsexual, leaving aside the diversities and the pluralities that exist in each experience.
\end{abstract}

\section{Keywords}

Transsexuality. Representation. Queer Studies. Telenovela.

Recebido em 14/08/2018

Aceito em 22/05/2019 